\title{
Music Therapy and Hormonal Responses in Autism
}

\author{
Otizmde Müzik Terapisi ve Hormonal Yanıtlar
}

\section{Elvan İşeri ${ }^{1}$, Esra Guney ${ }^{1}$, Rahmi Oruc Guvenc ${ }^{2}$, Azize Andrea Guvenc ${ }^{2}$, Mehmet Fatih Ceylan ${ }^{3}$, Ersan Cırak ${ }^{4}$ Banu Caycl ${ }^{5}$, Burak Bahar ${ }^{5}$, Sahnur Sener ${ }^{1}$}

\footnotetext{
${ }^{1}$ Department of Child and Adolescent Psychiatry, Gazi University Medical Faculty, Ankara, Turkey.

${ }^{2}$ Music therapist, Tümata Musical Group, Ankara, Turkey

${ }^{3}$ Department of Child and Adolescent Psychiatry, Yildirim Beyazit University Medical Faculty, Ankara, Turkey

${ }^{4}$ Dentist, Tümata Musical Group, Ankara, Turkey

${ }^{5}$ Department of Biochemistry, Gazi University Medical Faculty, Ankara, Turkey.
}

\section{ABSTRACT}

Objective: Music therapy is used in the treatment of various psychiatric and physical disorders. This study aims to explore the efficiency of, and neurohormonal responses to, music therapy in children with autism.

Methods: The effect of music therapy sessions of five hours a month on the severity of autism, verbal and social communication, behavior, and neurohormonal responses were explored in 10 children and adolescents. Autism severity was assessed using the Childhood Autism Rating Scale (CARS).

Results: The results of the study indicate that music therapy decreases hyperkinetic activity and stereotypical-repetitive behaviors while increasing mutual social interaction and verbal communication. In addition, the severity of autistic symptoms assessed by CARS significantly decreased following the therapy. When pre- and post-therapy hormone levels were compared, cortisol, ACTH, adrenaline, and noradrenaline levels were not significantly different.

Conclusion: Music therapy is a means of communication without words in children and adolescents with autism, and is an effective and important treatment option when accompanied by special educational support and individual psychotherapy in the treatment of autistic disorder.

Key Words: Music therapy, autism, cortisol, ACTH, adrenaline, noradrenaline

Received: 03.31 .2014

Accepted: 04.22.2014

\section{ÖZET}

Amaç: Müzik terapisi çeşitli psikiyatrik ve fiziksel hastalıkların tedavisinde kullanılmaktadır. Bu çalışmada, otistik bozukluk tanısı almış çocuklarda müzik terapisinin etkinliğinin ve müzik terapisine nörohormonal yanıtların araştırılması amaçlanmıştır.

Yöntem: Otistik bozukluk tanısı almış 10 çocuk ve ergene ayda bir kez, beş saat uygulanan müzik terapi seanslarının otizmin şiddeti ve sözel iletişim, sosyal etkileşim, davranış alanlarına yönelik etkinliği ve terapiye nörohormonal yanıtlar araştırılmıştır. Otizmin şiddeti Çocukluk Otizmi Değerlendirme Ölçeği (ÇODÖ) ile ölçülmüştür. Müzik terapisinin stres hormonları üzerine etkisinin incelenmesi amacıyla terapi öncesi ve sonrası plazma kortizol, ACTH, adrenalin ve noradrenalin düzeyleri incelenmiştir.

Bulgular: Çalışma sonuçları, müzik terapisinin hiperkinezik hareketliliği ve basmakalıp-yineleyici davranışları azalttığını; karşılıklı sosyal etkileşimi ve sözel iletişimi arttırdığını ortaya koymaktadır. Terapi sonrasında çODÖ ile değerlendirilen otistik belirtilerin şiddetinde de anlamlı azalma saptanmıştır. Terapi öncesi ve sonrası hormon düzeyleri karşılaştırıldığında; kortizol, ACTH, adrenalin ve noradrenalin düzeyleri arasında istatistiksel açıdan anlamlı fark bulunmamıştır.

Tartışma: Müzik terapisi otistik bozukluğu olan çocuk ve ergenlerde sözcüklerin kullanılmadığı bir iletişim aracı ve otistik bozukluğun tedavisinde özel eğitim desteği ve bireysel psikoterapilere eklenebilecek etkili ve önemli bir terapi seçeneğidir.

Anahtar Sözcükler: Müzik terapisi, otizm, kortizol, ACTH, adrenalin, noradrenalin

Geliş Tarihi:31.03.2014

Kabul Tarihi: 22.04.2014

Address for Correspondence / Yazışma Adresi: Esra Guney, MD, Department of Child and Adolescent Psychiatry, Gazi University Medical Faculty, Ankara, Turkey, Phone: +90 5056406895 E-mail: dresraguney@gmail.com

(CTelif Hakkı 2014 Gazi Üniversitesi Tıp Fakültesi - Makale metnine http://medicaljournal.gazi.edu.tr/ web adresinden ulaşılabilir. (C) Copyright 2014 by Gazi University Medical Faculty - Available on-line at web site http://medicaljournal.gazi.edu.tr/ doi: http://dx.doi.org/12996/gmj.2014.16 
INTRODUCTION

Autism is a neurodevelopmental disorder characterized by the deterioration of verbal and non-verbal communication, and limited and stereotypic interest and behavior (1). It is usually diagnosed at 24 to 36 months; however, caregivers are often able to observe its symptoms at 12 to 18 months (2). In some cases, diagnosis may come later in life during adulthood (1)

The prevalance of autism has been estimated to vary from $5 / 10,000$ to $63 / 10,000(3,4)$. Clinical manifestations of the disorder are variable, from severe learning difficulties, to superior skills in specific functions due to differing levels of cognitive capacity. Despite the differences in both behavioral symptoms and functioning, restrictions can be determined early. Social interaction, verbal communication, behavior, and imagination are core domains of the disorder (5).

Conventional interventions such as therapy and special education support help increase verbal communication and social interaction. However, due the the numerous problems associated with these interventions, the search for alternative treatments continues (6). Music therapy has been used in the treatment of autistic children worldwide since reports that musical activity for the purpose of treatment positively affected communication, interaction, motivation, attention, and sustainability in autistic children (7).

Music therapy has been defined as "a systematic intervention applied by therapist to help adjusting for the patient's health using musical experience and closeness (relationship) that develops between patient and him or herself" (8), and is used in the treatment of many psychiatric and physical disorders. Some studies have reported that when used for a supportive and palliative purpose, music therapy was found to be effective in decreasing agitation, anxiety, and depressive symptoms. Moreover, it decreased the need for the medical treatment of patients with Alzheimer's disease, cancer, chronic pain syndromes, and those requiring gastroscopy or even more severe interventions (9-14).

Similarly, it has been reported that music therapy may improve symptoms of anxiety and depression, and increase functioning in patients with autism and schizophrenia (11). According to a study conducted by Kim et al. (2008), music therapy has been found to be more effective than play in terms of increased attention and non-verbal communication in autistic children (15). In another study which evaluated eight autistic adults, music therapy was shown to positively affect behavior, and increase functioning (16). Music therapy is an interaction area within which words are unnecessary, and can be used as a tool to treat autistic children and adolescents (17).

It has been reported that music therapy decreases anxiety and neurohormonal responses to psychologic stress (18). A relaxing musical experience has been shown to decrease the response of the hypothalamicpituitary-adrenal axis to stress, and the cortisol levels in saliva (19). There are some reports regarding a decrease in serum cortisol and norepinephrine (NE) levels in healthy volunteer subjects or applied stressful invasive procedures, such as surgery or gastroscopy as a response to classical or relaxing music $(20,21)$. There have also been reports that found no difference in the levels of growth hormones, cortisol, NE, epinephrine, prolactin, and ACTH $(22,23)$. Music therapy has been reported to increase feelings of wellbeing, and decrease anxiety and stress, although these are controversial results $(21,24)$.

The current study aimed to evaluate the effect of music therapy on autistic children, as well as any neurohormonal response. Interestingly, no studies evaluating neurohormonal response were found in the literature, and very few studies examined the effect of music therapy on autistic children. There are no studies evaluating the effect of music therapy on autism in Turkey. Thus, this research makes a valuable contribution to the literature.

\section{METHODS}

\section{Samples}

Fourteen of a total of 27 children diagnosed with autistic disorder at the Gazi University Medical School Child Psychiatry Department according to the DSM-IV met the criteria for inclusion in the study, and were followed by the outpatient clinic between August 2006 and August 2007. The 14 patients received regular music therapy sessions over the period betwen August 2007 and April 2008. Four patients were excluded from the study sample due to their irregular attendance.
The 10 remaining patients ( 6 male, 4 female) were between 6 to 15 years of age (mean age was $9.7 \pm 3.74$ years). The patients received one fivehour music therapy session per month, for a total of four to eight months (mean $5.40 \pm 1.71$ ). Patients diagnosed with neurodegenerative or metabolic disorders, infectious diseases, and severe visual, auditory, or motor deficits were excluded from the sample. Patients using psychotropic drugs were excluded as well in order to prevent the potential impact of drugs on study results.

Information on music therapy, and the aim of the study and its method was disclosed to the parents of the patients, and their approvals and the consent of Gazi University Medical School Ethic Board was obtained.

\section{Tools}

Patients followed by the Child Psychiatry outpatient clinic were evaluated in detail by two child psychiatrists, and diagnosis was confirmed to be autism using DSM-IV criteria.

The Childhood Autism Rating Scale (CARS) was used to determine the severity of the autism. The scale was developed in order to differentiate between autism and other developmental disorders (25). It consisted of 15 items which determine the severity of autism-related symptoms, categorized under the following headings: relationships with people, imitation, emotional reactions, use of the body, use of the object, adaptability to change, visual and listening response, taste, smell and touch response and their use, fear/nervousness, verbal and non-verbal communications, activity level, mental reaction volume and its consistency, and general impressions.

Every item is rated on a scale of 1 (normal) to 4 (severely abnormal), with a half-degree scoring $(1,1.5,2,2.5,3,3.5$, and 4). A total score of 30 and above supports the presence of autism (25). A score of 30 to 36.5 indicates mild-to-moderate autism, and a score of 37 to 60 indicates severe autism (26). The Turkish version of CARS was established by Sucuoglu a colleagues (27). CARS scores for each patient were obtained pre- and posttherapy by the same interviewer.

Before starting the therapy sessions, a structured interview was carried out with parents which contained a grading scale ranging from 0 (normal) to 10 (severely abnormal) which concerned the limitations and difficulties of their childrens' language/verbal communication, social interaction, and behavior.

In the field of language/verbal communication, lack of speech, limitation of meaningful vocabulary, inability to start and maintain spontaneous verbal communication, lack of appropriate verbal responses, the presence of speech disorders such as echolalia, speaking without subject, predicate, or emphasis, mismatch between words and meaning, and incorrect use of grammar were questionned.

In the social interaction domain, social unresponsiveness to smiling or calling, avoidance of physical contact, inability to start and sustain interpersonal non-verbal communication, lack of meaningful gestures and facial expressions, failure to join in with group play, and reluctance to participate in common activities were evaluated.

In the field of behavior, stereotypic and repetitive movements, inappropriate behavior that could harm the self and others, hyperkinetic activity, irritability, and resistance to change scores were determined. After the last therapy, the structured interview was repeated.

\section{Music Therapy}

A number of instruments such as the tar, dombra, rhythm equipment, ceng, violin, strings, kabak kemane (gicek, kemence), tanbur, kanun, ney, kılkopuz, rubab (kockarca), and gurgle may be used in the process of music therapy. In the current study conducted by Gazi University, live music was performed by the Tumata Group using specifically selected instruments, namely the tar (a stringed instrument made from mulberry wood and covered with skin), kopuz (Turkish kopuz, a fretless stringed instrument), ney (an end-blown flute made from cane), and gurgle (sound of water). In addition, children were allowed to play these instruments under the supervision of the team.

\section{Blood Sampling}

Serum cortisol, epinephrine, NE, and $\mathrm{ACTH}$ levels of all patients were analyzed pre- and post-therapy. ACTH and cortisol concentrations were studied with the immunochemiluminescence method using the DiaSorin Liaison autoanalyzer kit (29). 
Epinephrine and NE levels were determined with the radioimmunoassay method using the Labor Diagnostika Nord RIA kit. Normal range of hormones was accepted as falling between 4.5 and $24 \mu \mathrm{g} / \mathrm{dL}$ for cortisol, 0 and 100 $\mathrm{pg} / \mathrm{mL}$ for epinephrine, 0 and $600 \mathrm{pg} / \mathrm{mL}$ for $\mathrm{NE}$, and 4.7 and $48.8 \mathrm{pg} / \mathrm{mL}$ for ACTH.

\section{Statistical Analysis}

For statistics, the SPSS (Windows 11.5) programme was used. The Wilcoxon Signed Ranks Test was used to compare the biochemical parametres of pre- and post-therapy, and the scores of language/verbal communication, social interaction, and behavior domains. The relationships between variables were analyzed using the Pearson correlation test. $p<0.05$ was accepted as statistically significant.

\section{RESULTS}

Ten patients ( 6 male and 4 female), between 6 to 15 years of age (mean age $9.7 \pm 3.74$ years) were evaluated. CARS were used to confirm clinical diagnosis, and evaluate the severity of each patient's autism. The scale was applied again after the last music therapy session to determine the potential difference between autistic behaviors. CARS scores evaluated at the last therapy session were found to be significantly lower than the pre-therapy scores $(z=-2.652, p=0.008)$ (Table 1$)$.

The structured interviews which evaluated the limitations and difficulties in language/verbal communication, social interaction, and behavior fields, using a grading scale from 0 (normal) to 10 (severely abnormal), were carried out with the parents. The degree of difficulties determined by parents in language/verbal communication, social interaction, and behavior fields was significantly lower after the last therapy session as compared with the pretherapy session (Table 1).

Table 1

Mean levels of CARS and language/verbal communication, social interaction, and behavior scale scores pre- and post-music therapy

\begin{tabular}{|c|c|c|c|c|}
\hline & $\begin{array}{l}\text { Pre- } \\
\text { theraphy } \\
\text { (Mean } \pm \text { SD) }\end{array}$ & $\begin{array}{l}\text { Post- } \\
\text { theraphy } \\
\text { (Mean } \quad \pm \\
\text { SD) }\end{array}$ & $\mathbf{Z}$ & $p^{a}$ \\
\hline CARS total score & $40.95 \pm 6.93$ & $35.05 \pm 7.65$ & -2.652 & 0.008 \\
\hline Language/verbal & $7.00 \pm 1.76$ & $5.90 \pm 2.60$ & -2.041 & 0.041 \\
\hline communication & $6.20 \pm 1.31$ & $5.20 \pm 1.81$ & -2.264 & 0.024 \\
\hline $\begin{array}{l}\text { Social interaction } \\
\text { Behaviour }\end{array}$ & $6.70 \pm 0.94$ & $4.30 \pm 1.70$ & -2.680 & 0.007 \\
\hline
\end{tabular}

\section{Behaviour}

SD: Standard deviation, CARS: Childhood Autism Rating Scale

${ }^{a}$ Wilcoxon Signed Ranks Test

Language/verbal communication, social interaction and behavior scale scores were correlated with the number of sessions. A negative correlation was found at a significantly moderate level, such that as the number of sessions increased, the scores on the behavior scale decreased $(p=0.056$; $r=0.621$ ). There were no significant differences between the number of sessions and the rest of the scores (for language/verbal communication $p=0.322$ and $r=0.350$, and for social interaction $p=0.636$ and $r=0.171$ ). There was also no relationship between the number of sessions and CARS scores $(p=0.520$ and $r=0.231)$.

In the second part of the study, the effect of music therapy on stress hormones cortisol, epinephrine, NE, and ACTH were evaluated for all patients. No statistically significant difference was found between the levels of hormones measured in the pre- and post-therapy period (Table 2).

Table 2. Comparison of mean hormone levels of subjects at pre- and postmusic therapy

\begin{tabular}{lllll}
\hline & $\begin{array}{l}\text { Pre-theraphy } \\
\text { (Mean } \pm \text { SD) }\end{array}$ & $\begin{array}{l}\text { Post- } \\
\text { theraphy } \\
\text { (Mean } \pm \text { SD) }\end{array}$ & Z & $\mathbf{p}^{\text {a }}$ \\
\hline Cortisol $(\mu \mathrm{g} / \mathrm{dL})$ & $8.78 \pm 3.83$ & $8.00 \pm 2.35$ & -0.968 & 0.333 \\
ACTH $(\mathbf{p g} / \mathrm{mL})$ & $24.63 \pm 10.34$ & $26.62 \pm 14.27$ & -0.764 & 0.445 \\
Adrenaline $(\mathbf{p g} / \mathrm{mL})$ & $64.07 \pm 39.21$ & $74.46 \pm 43.75$ & -1.632 & 0.103 \\
Noradrenaline & $144.72 \quad \pm$ & $115.52 \quad \pm$ & -0.051 & 0.959 \\
$(\mathrm{pg} / \mathrm{mL})$ & 122.53 & 49.05 & & \\
\hline
\end{tabular}

SD: Standard deviation, ACTH: Adrenocorticotropic hormon

${ }^{a}$ Wilcoxon Signed Ranks Test

\section{DISCUSSION}

The current study investigated music therapy and its effect on verbal communication, social interaction, and behavior fields in patients with autism, as well as their stress hormone levels. To our best knowledge, this is the first study investigating music therapy on autism in Turkey. The results clearly show that music therapy decreased hyperkinesic movements and stereotypic-repetitive behaviors, while increasing reciprocal social interaction and verbal communication. With therapy, patient's participation in common events, eye contact, meaningful vocabulary, and compliance with the environment significantly increased. In addition, the severity of autistic symptoms evaluated with CARS were found to have significantly decreased post-therapy.

These results are consistent with results conducted by Edgerton (1994) and Buday (1995) (30,31). Edgarton revealed that the communication skills of 11 children with autism between 6 and 9 years of age had significantly improved following improvised music therapy sessions once a week for 30 minutes over 10 weeks. Another study conducted by Buday compared music therapy with rhythm therapy (the repetition of a original song through speech using the same rhythm and speed but without music). Therapy was applied for four consecutive days over five sessions in 10 children with autism between 4 and 9 years of age. Music therapy was found to be more effective than rhythm therapy, as children applied aspects of the music therapy to their vocabulary more, and imitated more behavior.

In another study, eight autistic adults who received active music therapy over 52 weeks for 60 minutes each session were evaluated using the Clinical Global Impression (CGI) and Brief Psychiatric Rating Scale (BPRS), and the severity of autism was reported as significantly lower (16). Despite different methods and numbers of sessions, results indicated a significant decrease in autism symptoms and severity post-therapy, consistent with the current study. In a study with partially different results, Brownell (2002) followed four autistic children from 6 to 9 years of age over four weeks for sessions lasting five days (32). No therapy was applied in the first and third weeks. In the second week, children listened to a social story accompanied by music for five days. This was repeated, again for five days, in the last week but without music. A comparison between results of the music therapy with the no-music story sessions showed that music therapy decreased the repetitive behaviors of two children, whereas the other children's behaviors were unaffected. However, it is highly difficult to interpret these results due to the limited number of subjects. The current study supports these results which reported that music therapy increases the communication skills of autistic children and decreases their repetitive behaviors.

Music therapy decreases subjective stress. In a study conducted by Leardi, plasma cortisol, ACTH, epinephrine, and NE levels were determined pre- and post-therapy to evaluate the effect of music therapy on levels of stress hormones, but no significant difference was found (21). A comparison between the results of the current study and the other studies evaluating the neurohormonal response to music therapy in children with autism could not be actualized due to lack of studies. Some studies found that music therapy applied to healthy volunteers at rest or to patients who underwent medical interventions such as gastroscopy or surgery experienced a decreased level of stress hormones (20), while others found that therapy had no effect on these levels (23). The current study found no significant effect of music therapy on stress hormones.

As the current study failed to observe a neurohormonal change, the hypothesis that neurohormones such as cortisol, ACTH, epinephrine, and NE increase may be a mediator of effects such as an increase in the sense of subjective wellbeing and a decrease in the level of stress provided by music therapy could not be supported. However, increases in verbal communication, social interaction, and behavioral concordance were detected in patients who received music therapy. Results also showed that music therapy is correlated with a prominent decrease in autistic symptoms.

Music therapy enables communication without the use of words. Dialogue provided by music therapy has been shown to initiate and sustain personal and social interaction skills (33). Music therapy is an effective and important therapy option to complement specific education support and individual psychotherapy. 
The recent study has several limitations. The number of samples were restricted for the following reasons: a) the number of autistic children in the sample decreased over the study's diagnosis and collection period, b) after diagnosis, the specific education programmes of the autistic children overlapped with music therapy sessions, c) it was difficult to find children who met the requirements for the study and could regularly attend the therapy sessions, and d) the blood collection process created difficulties for some parents due to their children's behavioral difficulties.

\section{CONCLUSION}

Music therapy is an effective and important treatment option when accompanied by special educational support and individual psychotherapy in the treatment of autistic disorder. Further studies using larger samples and non-invasive methods, such as assessment of hormone levels in saliva, are required.

\section{Acknowledgments}

We would like to say our thanks to the "Tumata Musical Group" members (Yasar Guvenc, Emre Basaran, Neslihan Ozturk, Gulten Urallı, Hande Odabası, Serap Celik) due to their contributions for our study.

\section{Conflict of Interest}

No conflict of interest was declared by the authors.

\section{REFERENCES}

1. Filipek PA, Accardo P, Baranek GT, Cook EH Jr, Dawson G, Gordon $B$, et al. The screening and diagnosis of autistic spectrum disorders. J Autism Dev Disord 1999; 29: 439- 84.

2. Mitchell S, Brian J, Zwaigenbaum L, Roberts W, Szatmari P, Smith I, et al. Early language and communication development of infants later diagnosed with autism spectrum disorder. J Dev Behav Pediatr 2006; 27: 69-78.

3. Chakrabarti S, Fombonne E. Pervasive developmental disorders in preschool children. JAMA 2001; 285: 3093-99.

4. Fombonne E. The epidemiology of autism: A review. Psychological Medicine 1999; 29: 769-786.

5. Gold C, Wigram T, Elefant C. Music therapy for autistic spectrum disorder. Cochrane Database of Systematic Reviews 2006; 2: CD004381.

6. Corbett BA, Shickman K, Ferrer E. Brief Report. The Effect of Tomatis Sound Therapy on Language in Cildren with Autism. J Autism Dev Disord 2008; 38: 562-6.

7. Wigram T, Gold C. Music therapy in the assesment and treatment and teratment of autistic spectrum disorder: clinical application and research evidence. Child: care, health and development 2006; 32: 535- 42.

8. Bruscia KE. Defining music therapy. 2nd Edition. Gilsum NH, Barcelona Publishers, 1998, p. 20.

9. Ledger AJ, Baker FA. An investigation of long-term effects of group music therapy on agitation levels of people with Alzheimer'sDisease. Aging Ment Health 2007; 11: 330-38.

10. Boso M, Politi P, Barale F, Enzo E. Neurophysiology and neurobiology of the musical experience. Fuct Neurol 2006; 21:187-91.

11. Myskja A, Lindbaek M. Examples of the use of music in clinical medicine. Tidsskr Nor Laegeforen 2000; 120: 1186-90.

12. Escher J, Höhmann U, Anthenien L, Dayer E, Bosshard C, Gaillard RC. Music during gastroscopy. Schweiz Med Wochenschr 1993; 123: 1354-58.

13. Kumar AM, Tims F, Cruess DG, Mintzer MJ, Ironson G, Loewenstein $D$, et al. Music therapy increases serum melatonin levels with Alzheimer's disease. Altern Ther Health Med 1999; 5: 49-57.
14. Yıldırım S, Gürkan A. Müziğin, kemoterapi yan etkilerine ve kayg düzeyine etkisi. Anadolu Psikiyatri Dergisi 2007; 8: 37-45.

15. Kim J, Wigram T, Gold C. The effects of improvisational music therapy on joint attention behaviors in autistic children: A randomized controlled study. J Autism Dev Disord 2008; 38: 175866

16. Boso M, Emanuele E, Minazzi V, Abbamonte M, Politi P. Effect of long-term interactive music therapy on behavior profile and musical skills in young adults with severe autism. The Journal of Alternative and Complement Medicine 2007; 7: 709-12.

17. Bode $M$, Meyberg W. Music therapy in a child and adolescent psychiatry department. Prax Kinderpsychol Kinderpsychiatr 1992; 41: 293-97.

18. Smith JC, Joyce CA. Mozart versus new age music relaxation states, stress and ABC relaxation theory. J Music Ther 2004; 41: 215-24.

19. Khalfa S, Bella SD, Roy M, Peretz I, Lupien SJ. Effects of relaxing music on salivary cortisol level after psychological stress. Ann N Y Acad Sci 2003; 999: 374-76.

20. Möckel M, Röcker L, Störk T, Vollert J, Danne O, Eichstädt H, et al. Immediate physiological responses of healthy volunteers to differe nt types of music:cardiovasculer, hormonal vand mental changes. Eur J Appl Physiol Occup Physiol 1994; 68: 451-59.

21. Leardi S, Pietroletti R, Angeloni G, Necozione S, Ranalletta G, Del Gusto B. Randomized clinical trial examining the effect of music therapy in stress response to day surgery. British Journal of Surgery 2007; 94: 943-47.

22. Gerra G, Zaimovic A, Franchini D, Palladino M, Giucastro G, Reali $\mathrm{N}$, et al. Neuroendocrine responses of healthy volunteers to "techno- music": relationships with personality traits and emotional state. Int J Psychophysiol 1998; 28: 99-111.

23. Migneault B, Girard F, Albert C, Chouinard P, Boudreault D, Provencher $D$, et al. The effect of music on the neurohormonal stress response to surgery under general anesthesia. Anesth Analg 2004; 98: 527-32.

24. Hirokawa $E$, Ohira $H$. The effects of music listening after a stressful task on immune functions, neuroendocrine responses, and emotional states in college students. J Music Ther 2003; 40: 189-211.

25. Schopler E, Reichler J, De Vill R, Daly K. Towards objective classification of childhood autism: Childhood Autism Rating Scale (CARS). J Autism Dev Disorder 1980; 10: 91-103.

26. Saemundsen E, Magnusson P, Smari J, Sigurdardottir S. Autism diagnostic interview-revised and childhood autism rating scale: convergence and discrepancy in diagnosis autism. Journal of Autism and Developmental Disorders 2003; 33: 319-28.

27. Sucuoğlu B, Öktem F, Gökler B. Otistik çocukların değerlendirilmesinde kullanılan ölçeklere ilişkin bir çalışma. Psikiyatri, Psikoloji, Psikofarmakoloji 1996; 4: 117-21.

28. Odell WD, Horton R, Pandian MR, Wong J. The Use of ACTH and Cortisol Assays in the Diagnosis of Endocrine Disorders. Nichols Institute Publication, 1989.

29. Tunn S, Pappert G, Willnow P, Krieg M. Multicentre evaluation of enzyme-immunoassay for cortisol determination. J Clin Chem Clin Biochem 1990; 28: 929-35.

30. Edgerton $\mathrm{CL}$. The effect of improvisational music therapy on the communicative behaviours of autistic children. Journal of Music Therapy 1994; 31: 31-62.

31. Buday EM. The effects of signed and spoken words taught with music on sign and speech imitation by children with autism. Journal of Music Therapy 1995; 32: 189-202.

32. Brownell MD. Musically adapted social stories to modify behaviours in students with autism: four case studies. Journal of Music Therapy 2002; 34: 117-44.

33. Aldridge D, Gustorff D, Neugebauer L. A preliminary study of creative music therapy in the treatment of children with developmental delay. The Arts In Psychotherapy 1995; 22: 189205. 